\title{
PERAN STRES KERJA DALAM MEMEDIASI PENGARUH BEBAN KERJA DAN LINGKUNGAN KERJA TERHADAP KINERJA KARYAWAN
}

\author{
Ni Made Sapta Resita Putri ${ }^{1}$ \\ Agoes Ganesha Rahyuda ${ }^{2}$ \\ ${ }^{1,2}$ Fakultas Ekonomi dan Bisnis Universitas Udayana (Unud), Bali, Indonesia \\ email: saptaresita@gmail.com
}

\begin{abstract}
ABSTRAK
Tujuan organisasi dapat dicapai dengan kinerja SDM perusahaan. Kinerja yang buruk akan berdampak pada citra perusahaan dan tentunya memperlambat proses dalam mencapai tujuan organisasi. Penelitian ini dilakukan untuk mengetahui pengaruh beban kerja dan lingkungan kerja terhadap kinerja karyawan serta peran stres kerja sebagai variabel pemediasi. Penelitian ini mengambil 42 karyawan sebagai responden menggunakan kuesioner, dengan metode sampling jenuh. Teknik analisis data yang digunakan adalah analisis jalur. Hasil penelitian menunjukkan bahwa beban kerja berpengaruh negatif terhadap kinerja karyawan. Hasil lainnya menunjukkan bahwa lingkungan kerja berpengaruh positif terhadap kinerja karyawan. Stres kerja memiliki pengaruh negatif terhadap kinerja karyawan. Penelitian ini juga menemukan bahwa stres kerja memediasi pengaruh beban kerja dan lingkungan kerja terhadap kinerja karyawan. Berdasarkan hasil penelitian ini, diharapkan penelitian selanjutnya mampu meneliti kinerja karyawan dengan responden dan lokasi penelitian yang lebih kompleks. Hasil penelitian ini juga diharapkan dapat dijadikan referensi serta pertimbangan bagi perusahaan dalam mengambil keputusan terkait kinerja karyawan.
\end{abstract}

Kata kunci : kinerja karyawan, beban kerja, lingkungan kerja, stres kerja

\begin{abstract}
Organizational goals can be achieved with the company's HR performance. Poor performance will have an impact on the company's image and certainly slow down the process in achieving organizational goals. This study was conducted to determine the effect of workload and work environment on employee performance and the role of work stress as mediating variables. This study took 42 employees as respondents using a questionnaire, with a saturated sampling method. Path analysis was used. The results of the study indicate that workload has a negative effect on employee performance. Work environment has a positive effect on employee performance. Job stress has a negative influence on employee performance. This study also found that work stress mediates the effect of workload and work environment on employee performance. Based on the results of this study, it is expected that further research is able to examine the performance of employees with respondents and more complex research locations. The results of this study are also expected to be used as a reference and consideration for companies in decision making related to employee performance.

Keywords: employee performance, workload, work environment, work stress
\end{abstract}




\section{PENDAHULUAN}

Industri konveksi merupakan salah satu alternatif bisnis yang digemari. Industri konveksi mencakup pengolahan pakaian jadi dari tekstil/tenun yang kemudian diproduksi menjadi kemeja, pakaian olahraga, celana, maupun pakaian jadi lainnya. Hingga tahun 2016, tercatat sebanyak 1.082 bisnis konveksi di Bali dengan total nilai produksi mencapai Rp. 1.044.413.451 (Dinas Perindustrian dan Perdagangan Provinsi Bali, 2016)

Banyaknya bisnis konveksi di pasar membuat persaingan di antara perusahaan-perusahaan sejenis semakin ketat. Sumber daya manusia (SDM) menjadi salah satu faktor krusial perusahaan di tengah persaingan bisnis yang ada. Sumber daya manusia tidak hanya berperan dalam mencapai tujuan organisasi tetapi juga menentukan pencapaian perusahaan secara nyata dengan sumber daya yang tersedia (Darmawati, 2013). Tujuan organisasi dapat dicapai dengan kinerja SDM perusahaan. Kinerja SDM dapat dilihat dari kualitas dan kuantitas hasil dari pekerjaan yang dilakukan, serta ketepatan waktu penyelesaian pekerjaan. Kinerja yang buruk akan berdampak pada citra perusahaan dan tentunya memperlambat proses dalam mencapai tujuan organisasi. Lalai, kurang teliti serta kurangnya tanggung jawab dalam tugas merupakan contoh kinerja buruk karyawan.

Dalam usaha untuk meningkatkan profit perusahaan perlu berfokus pada beberapa hal, salah satunya adalah sumber daya manusia. Sumber daya manusia yang baik akan mampu melaksanakan aktivitas-aktivitas perusahaan dengan lebih maksimal dan meminimalisir kerugian. Darmawati (2013) mengatakan, sudah merupakan suatu kewajiban bagi perusahaan untuk mengelola SDM demi berkembangnya perusahaan.

Kinerja merupakan konsep yang penting bagi sebuah bisnis. Robbins (2006:260) menyatakan bahwa kinerja karyawan terdiri dari beberapa indikator yaitu kualitas, kuantitas, ketepatan waktu, efektivitas, dan kemandirian. Dampak kinerja yang baik dapat dilihat dari penyelesaian pekerjaan yang efektif (Robbins \& Judge, 2008) serta kinerja perusahaan yang baik (Setyawan, 2018). Kinerja yang tidak maksimal berdampak pada kualitas produk, produktivitas, jadwal pengiriman produk, dan performa keselamatan kerja yang akhirnya memengaruhi biaya perusahaan (Setyawan, 2018)

Bharata Sport and Fashion merupakan salah satu perusahaan di industri konveksi. Bharata Sport and Fashion memfokuskan produksinya pada pakaian jadi berupa pakaian olahraga serta seragam. Bharata Sport and Fashion memiliki peluang bisnis yang tinggi mengingat banyaknya permintaan akan jenis pakaian tersebut, baik dari instansi negeri, swasta, maupun sekolah. Bharata Sport and Fashion dengan posisinya sebagai salah satu leader market di Jembrana, membuat banyak pelanggan percaya akan hasil kerja yang memuaskan. Kendatipun demikian, masih ditemukan komplain-komplain dari pelanggan terkait hasil produksi pakaian yang mereka terima. Karyawan diharuskan untuk memiliki kinerja yang tinggi demi tercapainya tujuan perusahaan. Penurunan dalam kuantitas dan kualitas hasil kerja menunjukkan kinerja karyawan yang tidak maksimal. Kinerja yang tidak maksimal juga ditunjukkan oleh keterlambatan karyawan dalam menyelesaikan pekerjaan sesuai dengan data periode Januari hingga Juni 2018 pada Tabel 1. 
Tabel 1.

Data Keterlambatan Penyelesaian Order Bharata Sport and FashionJanuari - Juni 2018

\begin{tabular}{ccc}
\hline Bulan & Target Penyelesaian & Realisasi \\
\hline Januari & 2 minggu & 2 minggu \\
Februari & 4 minggu & 4 minggu \\
Maret & 12 minggu & 14 minggu \\
April & 12 minggu & 15 minggu \\
Mei & 12 minggu & 15 minggu \\
Juni & 12 minggu & 16 minggu \\
\hline
\end{tabular}

Sumber: Data sekunder, 2018

Penyelesaian order pada Bharata Sport and Fashion mengalami keterlambatan empat bulan berturut-turut. Order yang masuk pada bulan Januari dapat diselesaikan sesuai target, begitupun dengan order di bulan Februari yang masing-masing selesai dalam waktu tiga dan empat minggu. Bulan Maret hingga Juni terjadi keterlambatan dalam penyelesaian order dengan jarak penyelesaian terlama hingga satu bulan. Tabel 1. menunjukkan bahwa adanya peningkatan dalam keterlambatan penyelesaian order oleh karyawan Bharata Sport and Fashion. Keterlambatan penyelesaian order terjadi karena adanya kesalahankesalahan yang dilakukan karyawan dalam proses kerja. Karyawan sering melakukan kesalahan pada bagian sablon serta ukuran pakaian yang diproduksi. Hal ini kemudian memengaruhi kualitas barang menyebabkan adanya pengulangan dalam produksi. Hasil kerja ini akan berdampak pada citra perusahaan jika berlangsung terus-menerus. Pelanggan yang kecewa pun berpeluang untuk tidak lagi melakukan pemesanan, yang mengakibatkan berkurangnya pelanggan.

Hasil wawancara yang dilakukan dengan manajer sumber daya manusia Bharata Sport and Fashion menunjukkan bahwa kinerja karyawan dipengaruhi oleh beberapa hal yaitu beban kerja, lingkungan kerja serta stres kerja. Dikatakan bahwa kondisi lingkungan kerja yang kurang nyaman, membuat karyawan tidak leluasa dan kurang fokus dalam bekerja. Jumlah pesanan yang tidak jarang melebihi kapasitas kerja per karyawan pun membuat kinerja karyawan menurun. Kondisi-kondisi tersebut juga mampu membuat karyawan merasakan stres karena tekanan yang ada saat mereka bekerja yang kemudian berdampak pada penurunan kinerja. Hal ini dilihat dari perilaku karyawan yang suka menunda pekerjaan.

Penelitian yang dilakukan Pratama \& Satrya (2018) pada Dinas Perhubungan Provinsi Bali menunjukkan bahwa beban kerja berpengaruh positif dan signifikan terhadap stres kerja. Hal ini dikarenakan peningkatan beban kerja yang diiringi dengan kurangnya waktu dalam mengerjakan pekerjaan serta kurangnya kesempatan untuk bisa mengambil keputusan dalam bekerja mengakibatkan peningkatan stres kerja. Lestari \& Utama (2017) menyatakan bahwa beban kerja berpengaruh positif dan signifikan terhadap stres kerja. Yo \& Surya (2015) dalam penelitiannya mendapatkan hasil bahwa beban kerja dan stres kerja memiliki hubungan positif dan signifikan. Penelitian yang dilakukan Kusuma \& Soesatyo (2014) mendapatkan hasil bahwa beban kerja berpengaruh positif terhadap stres kerja. Shabbir \& Naqvi (2017) menyatakan bahwa beban 
kerja berpengaruh positif dan signifikan terhadap stres kerja. Penelitian oleh Rizky \& Afrianty (2018) pada Dinas Sosial Provinsi Jawa Timur menyatakan bahwa beban kerja mempengaruhi stres kerja secara positif signifikan. Wijaya (2018) menyatakan beban kerja berpengaruh positif terhadap stres kerja. Aujada, Saryadi, \& Nugraha (2015) menyatakan bahwa beban kerja berpengaruh positif signifikan terhadap stres kerja. Berdasarkan hasil penelitian sebelumnya, hipotesis yang diajukan dalam penelitian ini adalah:

$\mathrm{H}_{1}$ : Beban kerja berpengaruh positif terhadap stres kerja.

Kristanti (2017) dalam penelitiannya mendapatkan hasil adanya pengaruh negatif dan signifikan lingkungan kerja baik secara fisik maupun non fisik terhadap stres kerja. Hal ini menunjukkan bahwa lingkungan kerja yang semakin kondusif akan mampu mengurangi stres kerja karyawan. Penelitian yang dilakukan Syaharudin, Utami, \& Andini (2017) mendapatkan hasil lingkungan kerja berpengaruh negatif signifikan terhadap stres kerja. Penelitian tersebut menyatakan bahwa lingkungan kerja yang negatif dapat menyebabkan terjadinya peningkatan pada stres kerja dan menunjukkan terdapat pengaruh signifikan. Luma (2018) dalam penelitiannya menyatakan bahwa peningkatan lingkungan kerja guru dapat menurunkan stres kerja guru. Musyaddat \& Saufi (2017) menyatakan bahwa lingkungan kerja memiliki pengaruh negatif signifikan terhadap stres kerja. Penelitian oleh Rahajaan, Swasto, \& Rahardjo (2016) juga menyatakan lingkungan kerja berpengaruh negatif signifikan terhadap stres kerja. Berdasarkan hasil penelitian sebelumnya, maka hipotesis yang diajukan dalam penelitian ini adalah:

$\mathrm{H}_{2}$ : Lingkungan kerja berpengaruh negatif terhadap stres kerja

Beban kerja memiliki pengaruh negatif dan signifikan terhadap kinerja karyawan. Hal ini dijabarkan dalam penelitian yang dilakukan oleh Paramitadewi (2017). Pengaruh negatif beban kerja pada kinerja karyawan berarti bahwa semakin rendah beban kerja pegawai, kinerja karyawan akan semakin tinggi. Hasil serupa juga didapat oleh Kusuma \& Soesatyo (2014). Penelitian yang dilakukan Shabbir \& Naqvi (2017) mendapatkan hasil bahwa beban kerja berpengaruh negatif dan signifikan terhadap kinerja karyawan. Akob (2016) menyatakan bahwa beban kerja berpengaruh negatif terhadap kinerja karyawan. Hal yang sama juga dinyatakan oleh Wakoli (2016) dalam penelitiannya mengenai beban kerja terhadap kinerja guru di Bungoma, Kenya. Penelitian yang dilakukan oleh Chandra \& Adriansyah (2017) serta Iskandar \& Sembada (2012) menunjukkan bahwa adanya pengaruh negatif dan signifikan beban kerja terhadap kinerja karyawan. Gozali (2016) dalam penelitiannya menyatakan bahwa beban kerja berpengaruh negatif dan signifikan terhadap kinerja karyawan Badan Pusat Statistik di Kabupaten Deli Serdang dan Serdang Begawai. Mengacu pada hasil penemuan sebelumnya, maka hipotesis yang diajukan dalam penelitian ini adalah: $\mathrm{H}_{3}$ : Beban kerja berpengaruh negatif terhadap kinerja karyawan

Penelitian oleh Kristanti (2017) menunjukkan bahwa lingkungan kerja fisik berpengaruh positif dan signifikan terhadap kinerja karyawan. Penelitian ini juga menunjukkan adanya pengaruh positif dan signifikan lingkungan kerja non fisik terhadap kinerja karyawan. Hal ini menunjukkan bahwa semakin kondusif lingkungan kerja fisik dan lingkungan kerja non fisik yang ada maka kinerja 
karyawan akan meningkat. Nguyen, Dang, \& Nguyen (2015) dalam penelitiannya menyatakan bahwa lingkungan kerja berpengaruh positif dan signifikan terhadap kinerja karyawan. Jayaweera (2015) menyatakan adanya pengaruh positif dan signifikan dari lingkungan kerja terhadap kinerja karyawan. Penelitian terhadap karyawan universitas di Uganda oleh Wilson (2018) menunjukkan bahwa lingkungan kerja berpengaruh positif terhadap kinerja karyawan. Tulenan (2015) menyatakan bahwa lingkungan kerja berpengaruh positif signifikan terhadap kinerja karyawan. Harini \& Kartiwi (2018) menyatakan bahwa perbaikan pada lingkungan kerja dapat meningkatkan kinerja karyawan. Awaluddin (2016) dalam penelitiannya mengatakan lingkungan kerja berpengaruh positif terhadap kinerja karyawan. Penelitian oleh Dewi \& Frianto (2013) mendapatkan hasil yang serupa. Hipotesis yang diajukan dalam penelitian ini berdasarkan hasil penemuan sebelumnya adalah:

$\mathrm{H}_{4}$ : Lingkungan kerja berpengaruh positif terhadap kinerja karyawan

Penelitian mengenai stres kerja dan kinerja karyawan oleh Ahmad et al. (2018) menunjukkan pengaruh negatif dan signifikan stres kerja terhadap kinerja karyawan. Kotteeswari \& Sharief (2014) menyatakan bahwa stres kerja memengaruhi kinerja karyawan. Stres kerja membuat karyawan tidak mampu berkonsentrasi dengan baik pada pekerjaannya. Hasil serupa juga didapatkan pada penelitian Vijayan (2018), yang menyatakan bahwa manajemen bisa melakukan cara-cara yang diperlukan untuk bisa mengontrol tingkat stres kerja karyawan sehingga kinerja karyawan meningkat. Shahid (2012) menyatakan bahwa stres kerja berpengaruh negatif terhadap kinerja karyawan bank di Faisalabad, Pakistan. Ahmed \& Ramzan (2013) dalam penelitian pada sektor perbankan di Pakistan menyatakan bahwa stres kerja secara signifikan mengurangi kinerja karyawan. Saranani (2015) dan Kristanti (2017) menyatakan bahwa stres kerja berpengaruh negatif dan signifikan terhadap kinerja karyawan. Penelitian Kusuma \& Soesatyo (2014) juga menyatakan bahwa stres kerja berpengaruh negatif signifikan terhadap kinerja karyawan. Mengacu pada penemuan sebelumnya, maka hipotesis dalam penelitian ini adalah:

$\mathrm{H}_{5}$ : Stres kerja berpengaruh negatif terhadap kinerja karyawan

Stres di tempat kerja dapat menjadi masalah serius bagi organisasi maupun karyawan. Salah satu dampak nyata dari stres kerja adalah menciptakan ketidakseimbangan antara kemampuan individu, kebutuhan, dan harapan serta apa yang organisasi minta untuk dilakukan individu (Alkubaisi, 2015). Beban kerja dapat memengaruhi kinerja karyawan dan stres kerja.Penelitian oleh Shabbir \& Naqvi (2017) menunjukkan adanya pengaruh positif beban kerja terhadap stres kerja dan berpengaruh negatif terhadap kinerja karyawan. Shabbir \& Naqvi (2017) juga menyatakan bahwa stres kerja memediasi pengaruh beban kerja terhadap kinerja karyawan.Berdasarkan pemikiran di atas, hipotesis yang diajukan dalam penelitian ini adalah:

$\mathrm{H}_{6}$ : Stres kerja memediasi pengaruh beban kerja terhadap kinerja karyawan

Lingkungan kerja mampu memengaruhi kinerja karyawan dan stres kerja. Penelitian yang dilakukan Khuong \& Yen (2017) pada enam industri berbeda Vietnam menunjukkan hasil bahwa lingkungan kerja dan stres kerja mampu memengaruhi kinerja karyawan. Hasil dari penelitian ini menyatakan pula bahwa 
stres kerja memediasi pengaruh lingkungan kerja terhadap kinerja karyawan. Berdasarkan pemikiran di atas, hipotesis yang diajukan dalam penelitian ini adalah:

$\mathrm{H}_{7}$ : Stres kerja memediasi pengaruh lingkungan kerja terhadap kinerja karyawan

\section{METODE PENELITIAN}

Penelitian ini merupakan penelitian kuantitatif. Desain penelitian ini disusun untuk mengetahui serta memberikan gambaran secara sistematis tentang informasi yang berasal dari variabel penelitian. Penelitian ini dilakukan di Bharata Sport and Fashion yang beralamat di Jl. Ngurah Rai No.36, Loloan Timur, Kec. Jembrana, Kabupaten Jembrana. Objek dalam penelitian ini adalah beban kerja $\left(\mathrm{X}_{1}\right)$, lingkungan kerja $\left(\mathrm{X}_{2}\right)$, stres kerja $(\mathrm{M})$, dan kinerja karyawan $(\mathrm{Y})$ pada karyawan Bharata Sport and Fashion. Variabel endogen dalam penelitian ini adalah kinerja karyawan (Y). Variabel mediasi dalam penelitian ini adalah stres kerja (M). Variabel eksogen dalam penelitian ini adalah beban kerja $\left(\mathrm{X}_{1}\right)$ dan lingkungan kerja $\left(\mathrm{X}_{2}\right)$.

Data kuantitatif yang digunakan dalam penelitian ini adalah data jumlah karyawan Bharata Sport and Fashion, data keterlambatan penyelesaian order pada Bharata Sport and Fashion, serta usia responden dan skor jawaban responden dalam kuesioner. Data kualitatif yang digunakan dalam penelitian ini berupa identitas responden kuesioner serta hasil wawancara dengan manajer sumber daya manusia Bharata Sport and Fashion. Sumber primer dalam penelitian ini berupa respon karyawan terhadap kuesioner yang diberikan, serta hasil wawancara dengan manajer sumber daya manusia Bharata Sport and Fashion. Sumber sekunder dalam penelitian ini berupa profil perusahaan dan data keterlambatan penyelesaian orderBharata Sport and Fashion. Populasi dan sampel dalam penelitian ini adalah 42 karyawan Bharata Sport and Fashion. Metode penentuan sampel yang digunakan adalah teknik sampling jenuh. Untuk memperoleh data, penelitian menggunakan teknik pengumpulan data dengan menggunakan metode wawancara dan survei.

Tabel 2.

Data Jumlah Karyawan Bharata Sport and Fashion

\begin{tabular}{cc}
\hline Posisi & Jumlah \\
\hline Bagian order & 2 \\
Penjahit & 15 \\
Bagian pemotongan & 3 \\
Bagian sablon & 3 \\
Bagian sortir & 3 \\
Bagian packing & 3 \\
Bagian setrika & 3 \\
Bagian gudang & 4 \\
Designer & 1 \\
Marketing & 3 \\
Supervisor & 2 \\
Total & $\mathbf{4 2}$ \\
\hline
\end{tabular}

Sumber: Data sekunder diolah, 2018. 


\section{HASIL DAN PEMBAHASAN}

Karakteristik responden merupakan data responden yang dikumpulkan untuk mengetahui profil responden penelitian. Penelitian ini menggunakan sampel 42 karyawan Bharata Sport and Fashion. Berikut data identitas responden berdasarkan jenis kelamin, usia, tingkat pendidikan, dan masa kerja responden yang disajikan pada Tabel 3.

Tabel 3.

Karakteristik Responden

\begin{tabular}{|c|c|c|c|c|}
\hline No & Karakteristik & Klasifikasi & $\begin{array}{c}\text { Jumlah } \\
\text { Responden } \\
\text { (orang) }\end{array}$ & $\begin{array}{c}\text { Presentase } \\
\text { Responden } \\
(\%)\end{array}$ \\
\hline \multirow{2}{*}{1} & \multirow{2}{*}{ Jenis Kelamin } & Laki-Laki & 17 & 40,5 \\
\hline & \multirow{2}{*}{\multicolumn{2}{|c|}{ Perempuan }} & 25 & 59,5 \\
\hline \multirow{6}{*}{2} & & & 42 & 100 \\
\hline & \multirow{5}{*}{ Usia } & $19-25$ Tahun & 16 & 38,1 \\
\hline & & 26 - 32 Tahun & 15 & 35,7 \\
\hline & & 33 - 39 Tahun & 6 & 14,3 \\
\hline & & 40 - 46 Tahun & 2 & 4,8 \\
\hline & & $>46$ Tahun & 3 & 7,1 \\
\hline & \multicolumn{2}{|c|}{ Jumlah } & 42 & 100 \\
\hline \multirow{5}{*}{3} & \multirow{5}{*}{$\begin{array}{c}\text { Tingkat } \\
\text { Pendidikan }\end{array}$} & SMA/SMK & 42 & 100 \\
\hline & & D1 & 0 & 0 \\
\hline & & $\mathrm{D} 2$ & 0 & 0 \\
\hline & & D3 & 0 & 0 \\
\hline & & S1 & 0 & 0 \\
\hline \multirow{5}{*}{4} & \multicolumn{2}{|c|}{ Jumlah } & 42 & 100 \\
\hline & \multirow{3}{*}{ Masa Kerja } & 1 - 5 Tahun & 31 & 73,8 \\
\hline & & $6-10$ Tahun & 6 & 14,3 \\
\hline & & $>10$ Tahun & 5 & 11,9 \\
\hline & \multicolumn{2}{|c|}{ Jumlah } & 42 & 100 \\
\hline
\end{tabular}

Sumber: Data primer diolah, 2019

Pada Tabel 3. di atas dapat dilihat sebagian besar responden berjenis kelamin perempuan, karena karyawan perempuan sangat dibutuhkan dalam proses produksi pakaian, terutama diproses penjahitan hingga penyablonan barang. Dalam penelitian ini, usia 19 - 25 tahun merupakan usia yang paling mendominasi di antara yang lainnya, hal ini dikarenakan perusahaan melaksanakan perekrutan karyawan baru secara teratur dan sudah ditetapkan jadwalnya sehingga karyawan dominan masih tergolong muda. Jika dilihat dari karakteristik responden pada tingkat pendidikan, seluruh responden merupakan lulusan SMA/SMK, karena kualifikasi minimal bagi seseorang untuk masuk ke perusahaan sebagai karyawan adalah SMA/SMK, yang diutamakan dalam perekrutan karyawan adalah keterampilan dan disiplin. Masa kerja karyawan yang paling mendominasi adalah 1 - 5 tahun, hal ini dikarenakan perusahaan memerlukan karyawan yang tergolong muda pada proses produksi sehingga dilakukan proses perekrutan karyawan secara terjadwal. 
Tabel 4.

Rekapitulasi Hasil Uji Validitas Instrumen Penelitian

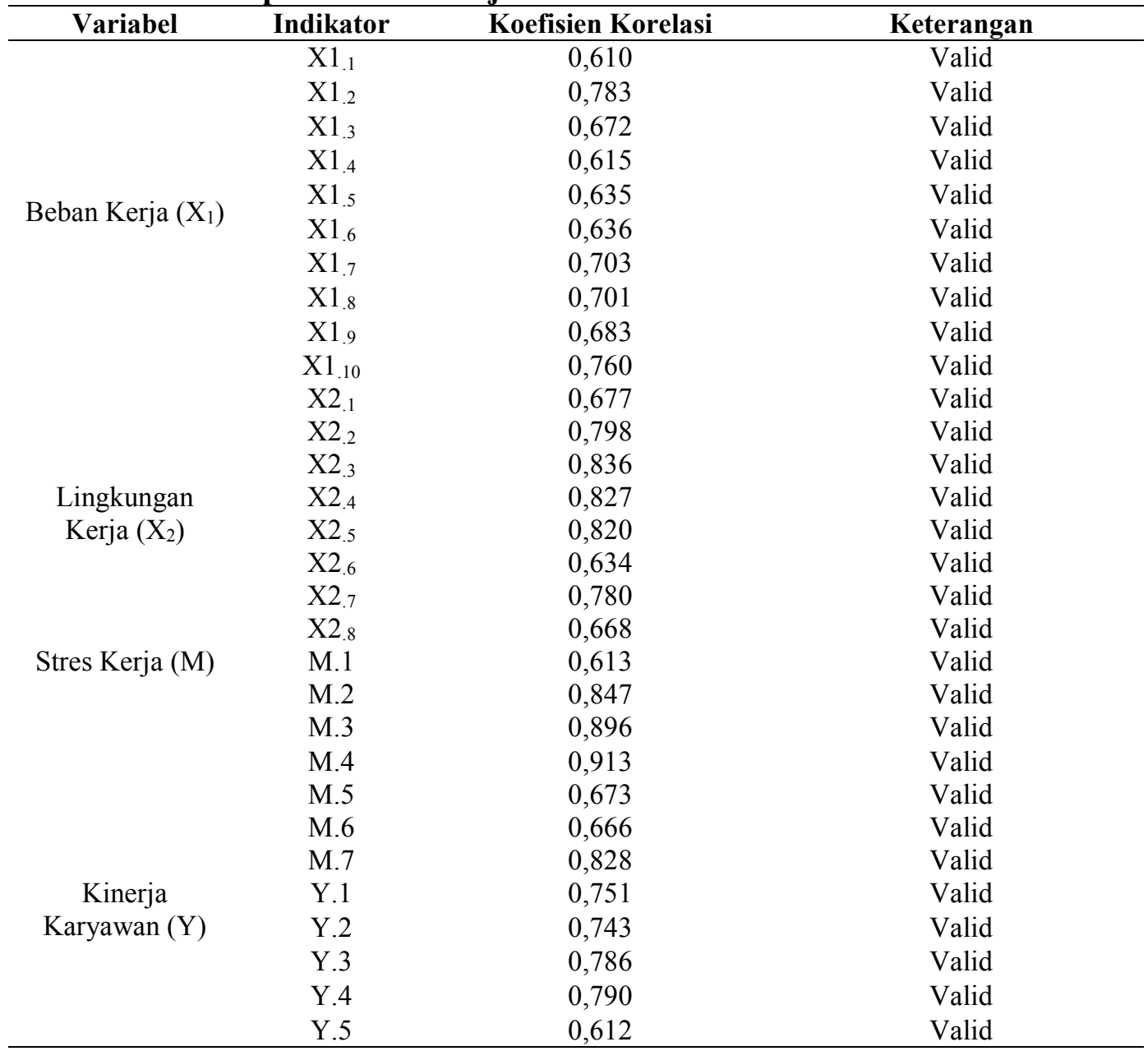

Sumber: Data primer diolah, 2019

Hasil uji validitas pada Tabel 4. menunjukkan bahwa seluruh instrumen penelitian yang digunakan untuk mengukur variabel beban kerja, lingkungan kerja, stres kerja, dan kinerja karyawan memiliki nilai koefisien korelasi dengan skor total seluruh item pernyataan lebih besar dari koefisien batas yakni 0,30 . Hal ini menunjukkan bahwa butir-butir pernyataan dalam kuesioner tersebut valid dan layak digunakan.

Tabel 5.

Rekapitulasi Hasil Uji Reliabilitas Instrumen Penelitian

\begin{tabular}{cccc}
\hline No. & Variabel & $\begin{array}{c}\text { Cronbach's } \\
\text { Alpha }\end{array}$ & Keterangan \\
\hline 1 & Beban Kerja $\left(\mathrm{X}_{1}\right)$ & 0,870 & Reliabel \\
2 & Lingkungan Kerja $\left(\mathrm{X}_{2}\right)$ & 0,893 & Reliabel \\
3 & Stres Kerja $(\mathrm{M})$ & 0,895 & Reliabel \\
4 & Kinerja Karyawan $(\mathrm{Y})$ & 0,789 & Reliabel \\
\hline Sumber: & &
\end{tabular}


Hasil uji reliabilitas yang disajikan dalam Tabel 5. menunjukkan bahwa seluruh instrumen penelitian memiliki koefisien Cronbach's Alpha lebih dari 0,6. Jadi dapat dinyatakan bahwa seluruh variabel telah memenuhi syarat reliabilitas sehingga dapat digunakan untuk melakukan penelitian.

Variabel beban kerjadalam penelitian ini merupakan variabel bebas yang diukur dengan menggunakan 10 pernyataan yang berhubungan dengan beban kerjadari responden. Karyawan secara keseluruhan nilai beban kerja yaitu 3,11 yang masuk dalam kategori cukup tinggi. Nilai rata-rata tertinggi terdapat pada pernyataan "saya gelisah jika tidak menyelesaikan pekerjaan tepat waktu". Hal ini menunjukkankaryawan setuju jika mereka gelisah saat tidak menyelesaikan pekerjaan tepat waktu.Nilai rata-rata terendah terdapat pada pernyataan "Saya memiliki waktu luang lebih sedikit dari semestinya (reversed question)". Hal ini menunjukkan bahwa karyawan tidak setuju jika mereka dikatakan memiliki waktu luang lebih sedikit dari semestinya. Mereka merasa masih memiliki waktu luang di sela-sela kesibukan mereka pada pekerjaan.

Variabel lingkungan kerja dalam penelitian ini merupakan variabel bebas yang diukur dengan menggunakan 8 pernyataan yang berhubungan dengan lingkungan kerja dari responden. Lingkungan kerja di perusahaan secara keseluruhan cukup baik yang dilihat dari keseluruhan rata-rata nilai lingkungan kerja yaitu 3,21. Nilai rata-rata tertinggi terdapat pada pernyataan "tempat kerja saya memiliki hubungan harmonis di antara karyawan". Hal inimenunjukkan bahwa karyawan merasa kalau tempat kerja mereka sudah memiliki hubungan harmonis di antara karyawan.

Nilai rata-rata terendah terdapat pada pernyataan "saya memiliki tingkat kepekaan tinggi terhadap suara dalam pekerjaan saya". Hal ini menunjukkan bahwa hampir seluruh karyawan tidak memiliki tingkat kepekaan yang tinggi terhadap suara dalam pekerjaan mereka. Hal ini mengindikasikan bahwa lingkungan kerja mereka bising yang menyebabkan karyawan kesulitan untuk mendengarkan suara atau bunyi.

Variabel stres kerjadalam penelitian ini merupakan variabel mediasi yang diukur dengan menggunakan 7 pernyataan yang berhubungan dengan stres kerja. Secara keseluruhan rata-rata jawaban responden terhadap variabel stres kerja memiliki nilai sebesar 2,91 yang masuk dalam kategori cukup tinggi. Hasil penyebaran kuesioner menunjukkan bahwa pernyataan "Laju detak jantung saya meningkat selama bekerja di tempat kerja saya" memiliki nilai rata-rata paling tinggi, hal ini berarti karyawan setuju jika laju detak jantung mereka meningkat selama bekerja di tempat kerja mereka.Hal ini bisa disebabkan oleh rasa takut yang muncul saat karyawan tidak bisa menyelesaikan pekerjaannya tepat waktu.

Nilai rata-rata terendah terdapat pada pernyataan "Saya depresi karena pekerjaan saya". Hal ini menunjukkan bahwa karyawan tidak setuju jika dikatakan bahwa mereka depresi karena pekerjaan mereka. Karyawan memang merasa stres, namun stres kerja tersebut masih bisa diatasi sehingga tidak menimbulkan depresi.

Kinerja karyawan dalam penelitian ini merupakan variabel terikat yang diukur dengan menggunakan 5 pernyataan yang berhubungan dengan kinerja karyawan.Secara keseluruhan rata-rata jawaban responden cukup setuju terkait dengan variabel kinerja karyawan, di mana nilai rata-rata keseluruhan variabel 
untuk kinerja karyawan mendapatkan hasil sebesar 3,16. Nilai rata-rata tertinggi terdapat pada pernyataan "saya menyelesaikan pekerjaan dengan baik". Hal ini menunjukkan bahwa sebagian karyawan sudah menyelesaikan tugas mereka dengan cukup baik.

Nilai rata-rata terendah terdapat pada pernyataan "saya menggunakan sumber daya yang dibutuhkan untuk berproduksi oleh organisasi dengan maksimal". Hal ini menunjukkan bahwa karyawan belum bisa memaksimalkan penggunaan sumber daya yang dibutuhkan dalam proses produksi di perusahaan sehingga kinerja mereka juga belum maksimal.

Tabel 6.

Hasil Uji Normalitas Model Struktur 1

\begin{tabular}{lc}
\hline & Unstandardized Residual \\
\hline $\mathrm{N}$ & 42 \\
Kolmogorov-Smirnov & 0,106 \\
Asymp Sig(2-tailed) & 0,200 \\
\hline Sumber: Data primer diolah, 2019
\end{tabular}

Sumber: Data primer diolah, 2019

Berdasarkan Tabel 6. dapat dilihat bahwa nilai Kolmogorov Sminarnov (KS) sebesar 0,106 dan nilai Asymp Sig(2-tailed)sebesar 0,200. Hasil tersebut mengindikasikan bahwa model persamaan regresi tersebut berdistribusi normal karena nilai Asymp Sig(2-tailed)lebih besar dari nilai alpha 0,05.

Tabel 7.

Hasil Uji Normalitas Model Struktur 2

\begin{tabular}{lc}
\hline & Unstandardized Residual \\
\hline $\mathrm{N}$ & 42 \\
Kolmogorov-Smirnov & 0,093 \\
Asymp Sig(2-tailed) & 0,200 \\
\hline Simber Detapi pen
\end{tabular}

Sumber: Data primer diolah, 2019

Nilai Kolmogorov Sminarnov (K-S) sebesar 0,093 dan nilai Asymp Sig(2tailed) sebesar 0,200. Hasil tersebut mengindikasikan bahwa model persamaan regresi tersebut berdistribusi normal karena nilai Asymp Sig(2-tailed) lebih besar dari nilai alpha 0,05 .

Tabel 8.

Hasil Uji Heteroskedastisitas Model Struktur 1

\begin{tabular}{|c|c|c|c|c|c|c|}
\hline \multicolumn{7}{|c|}{ Coefficients $^{a}$} \\
\hline \multirow{2}{*}{\multicolumn{2}{|c|}{ Model }} & \multicolumn{2}{|c|}{$\begin{array}{l}\text { Unstandardized } \\
\text { Coefficients }\end{array}$} & $\begin{array}{l}\text { Standardized } \\
\text { Coefficients }\end{array}$ & $\mathrm{t}$ & Sig. \\
\hline & & $\mathrm{B}$ & Std. Error & Beta & & \\
\hline \multirow[t]{3}{*}{1} & (Constant) & 4,267 & 4,714 & & ,905 & ,371 \\
\hline & Beban Kerja &,- 065 &, 083 &,- 342 &,- 791 & ,434 \\
\hline & Lingkungan Kerja &, 005 & ,086 & ,023 &, 053 & ,958 \\
\hline
\end{tabular}

Sumber: Data primer diolah, 2019

Nilai signifikansi dari variabel beban kerja sebesar 0,43 dan nilai signifikansi dari variabel lingkungan kerja sebesar 0,958. Nilai tersebut lebih besar dari 0,05 yang berarti tidak terdapat pengaruh antara variabel bebas terhadap 
absolute residual. Dengan demikian, model yang dibuat tidak mengandung gejala heteroskedastisitas.

Tabel 9.

Hasil Uji Heteroskedastisitas Model Struktur 2

\begin{tabular}{|c|c|c|c|c|c|c|}
\hline \multicolumn{7}{|c|}{ Coefficients $^{a}$} \\
\hline \multirow{2}{*}{\multicolumn{2}{|c|}{ Model }} & \multicolumn{2}{|c|}{$\begin{array}{l}\text { Unstandardized } \\
\text { Coefficients }\end{array}$} & $\begin{array}{l}\text { Standardized } \\
\text { Coefficients }\end{array}$ & $\mathrm{t}$ & Sig. \\
\hline & & $\mathrm{B}$ & Std. Error & Beta & & \\
\hline \multirow[t]{4}{*}{1} & (Constant) & 1,427 & 1,435 & & ,995 & ,326 \\
\hline & Beban Kerja &,- 080 &, 025 & $-1,318$ & $-1,247$ &, 102 \\
\hline & Lingkungan Kerja &,- 003 & 027 &,- 041 &,- 098 & ,922 \\
\hline & Stres Kerja & ,093 & 025 & 1,185 & 1,680 &, 101 \\
\hline
\end{tabular}

Sumber: Data primer diolah, 2019

Nilai signifikansi dari variabel beban kerja sebesar 0,102 , nilai signifikan dari variabel lingkungan kerja sebesar 0,922 , dan nilai signifikan variabel stres kerja sebesar 0,101. Nilai tersebut lebih besar dari 0,05 yang berarti tidak terdapat pengaruh antara variabel bebas terhadap absolute residual. Dengan demikian, model yang dibuat tidak mengandung gejala heteroskedastisitas.

Tabel 10.

Hasil Uji Multikoleniaritas

\begin{tabular}{clcc}
\hline Persamaan Struktur & \multicolumn{1}{c}{ Variabel } & Tolerance & VIF \\
\hline $\mathrm{M}=\beta_{1} \mathrm{X}_{1}+\beta_{2} \mathrm{X}_{2}+\mathrm{e}_{1}$ & Beban Kerja $\left(\mathrm{X}_{1}\right)$ & 0,119 & 8,393 \\
& Lingkungan Kerja $\left(\mathrm{X}_{2}\right)$ & 0,119 & 8,393 \\
$\mathrm{Y}=\beta_{3} \mathrm{X}_{1}+\beta_{4} \mathrm{X}_{2}+\beta_{5} \mathrm{M}+\mathrm{e}_{2}$ & Beban Kerja $\left(\mathrm{X}_{1}\right)$ & 0,106 & 9,410 \\
& Lingkungan Kerja $\left(\mathrm{X}_{2}\right)$ & 0,101 & 9,945 \\
& Stres Kerja $(\mathrm{M})$ & 0,169 & 5,929 \\
\hline
\end{tabular}

Sumber: Data primer diolah, 2019

Nilai tolerance dan VIF dari variabel beban kerja, lingkungan kerja, dan stres kerja menunjukkan nilai tolerance untuk setiap variabel lebih besar dari $10 \%$ dan nilai VIF lebih kecil dari 10 yang berarti model persamaan regresi bebas dari multikolinearitas.

Tabel 11.

Hasil Analisis Jalur Model 1

\begin{tabular}{|c|c|c|c|c|c|}
\hline \multirow[t]{2}{*}{ Variabel } & \multicolumn{2}{|c|}{$\begin{array}{c}\text { Unstandardized } \\
\text { Coefficients }\end{array}$} & \multirow{2}{*}{$\begin{array}{c}\text { Standardized } \\
\text { Coefficients } \\
\text { Beta }\end{array}$} & \multirow{2}{*}{$\begin{array}{c}\mathrm{t} \\
\text { hitung }\end{array}$} & \multirow{2}{*}{$\underset{t}{\text { Sig. uj }}$} \\
\hline & $\mathrm{B}$ & Std. Error & & & \\
\hline (Constant) & 21.020 & 8.470 & & 2.482 & .017 \\
\hline Beban Kerja $\left(\mathrm{X}_{1}\right)$ & .323 & .149 & .414 & 2.175 & .036 \\
\hline $\begin{array}{l}\text { Lingkungan Kerja } \\
\left(\mathrm{X}_{2}\right)\end{array}$ & -.415 & .155 & -.512 & 2.686 & .011 \\
\hline R Square & 0,831 & & & & \\
\hline F Statistik & 96,121 & & & & \\
\hline Signifikansi Uji F & 0,000 & & & & \\
\hline
\end{tabular}


Nilai koefisien regresi variabel beban kerja bernilai positif dengan nilai signifikansi uji t kurang dari 0,05 dan nilai koefisien regresi variabel lingkungan kerja bernilai negatif dengan nilai signifikansi uji t kurang dari 0,05. Hal ini menunjukkan bahwa variabel beban kerja memiliki pengaruh positif yang signifikan terhadap variabel stres kerja dan variabel lingkungan kerja memiliki pengaruh negatif yang signifikan terhadap variabel stres kerja. Besarnya pengaruh variabel bebas terhadap variabel terikat yang ditunjukkan oleh nilai determinasi total (R Square) sebesar 0,831 mempunyai arti bahwa sebesar 83,1\% variasi stres kerja dipengaruhi oleh beban kerja dan lingkungan kerja, sedangkan sisanya sebesar $16,9 \%$ dijelaskan oleh faktor lain yang tidak dimasukkan ke dalam model.

Tabel 12.

Hasil Analisis Jalur Model 2

\begin{tabular}{|c|c|c|c|c|c|}
\hline \multirow[t]{2}{*}{ Variabel } & \multicolumn{2}{|c|}{$\begin{array}{l}\text { Unstandardized } \\
\text { Coefficients }\end{array}$} & \multirow{2}{*}{$\begin{array}{c}\text { Standardized } \\
\text { Coefficients } \\
\text { Beta }\end{array}$} & \multirow{2}{*}{$\stackrel{\mathrm{t}}{\mathrm{h}}$} & \multirow{2}{*}{$\underset{t}{\text { Sig. uji }}$} \\
\hline & $\mathrm{B}$ & Std. Error & & & \\
\hline (Constant) & 20.372 & 2.952 & & 6.901 & .000 \\
\hline Beban $\operatorname{Kerja}\left(X_{1}\right)$ & -.236 & .051 & -.384 & 4.623 & .000 \\
\hline $\begin{array}{l}\text { Lingkungan Kerja } \\
\left(\mathrm{X}_{2}\right)\end{array}$ & .253 & .055 & .396 & 4.644 & .000 \\
\hline Stres Kerja(M) & -.184 & .052 & -.234 & 3.554 & .001 \\
\hline R Square & 0,972 & & & & \\
\hline F Statistik & 442,715 & & & & \\
\hline Signifikansi Uji F & 0,000 & & & & \\
\hline
\end{tabular}

Nilai koefisien regresi variabel beban kerja dan stres kerja bernilai negatif dengan nilai signifikansi uji t kurang dari 0,05 sedangkan nilai koefisien regresi lingkungan kerja bernilai positif dengan nilai signifikan uji t kurang dari 0,05 . Hal ini menunjukkan bahwa variabel beban kerja dan stres kerja memiliki pengaruh negatif yang signifikan terhadap variabel kinerja karyawan sementara variabel lingkungan kerja memiliki pengaruh positif terhadap variabel kinerja karyawan. Besarnya pengaruh variabel bebas terhadap variabel terikat yang ditunjukkan oleh nilai determinasi total (R Square) sebesar 0,972 mempunyai arti bahwa sebesar 97,2\% dari kinerja karyawan dipengaruhi oleh variasi beban kerja, lingkungan kerja, dan stres kerja, sedangkan sisanya sebesar 2,8\% dijelaskan oleh faktor lain yang tidak dimasukkan ke dalam model.

Berdasarkan hasil analisis beban kerja terhadap stres kerja, diperoleh nilai signifikansi sebesar 0,036 dengan nilai koefisien beta 0,414 . Nilai signifikansi $0,036<0,05$ mengindikasikan bahwa $\mathrm{H}_{0}$ ditolak dan $\mathrm{H}_{1}$ diterima. Hasil ini dapat diartikan bahwa beban kerja berpengaruh positif terhadap stres kerja karyawan pada Bharata Sport and Fashion di mana semakin tinggi beban kerja yang karyawan terima, stres kerja akan semakin tinggi. Hal ini menandakan bahwa beban kerja mampu menyebabkan stres kerja.

Jika merujuk pada jawaban responden terhadap pernyataan mengenai beban kerja dalam kuisioner, didapatkan hasil bahwa karyawan merasa gelisah jika tidak 
menyelesaikan pekerjaannya tepat waktu. Kegelisahan karyawan dalam proses kerja mengindikasikan pada beban kerja yang tinggi. Sementara itu, stres kerja dilihat dari pernyataan laju detak jantung karyawan yang meningkat selama bekerja. Kegelisahan karyawan yang terjadi terus-menerus mempunyai kemungkinan untuk memengaruhi laju detak jantung karyawan.

Hasil penelitian ini sesuai dengan hasil penelitian sebelumnya oleh Pratama \& Satrya (2018) pada Dinas Perhubungan Provinsi Bali. Pada penelitiannya, Pratama \& Satrya (2018) menyatakan peningkatan beban kerja yang diiringi dengan kurangnya waktu dalam mengerjakan pekerjaan serta kurangnya kesempatan untuk bisa mengambil keputusan dalam bekerja mengakibatkan peningkatan stres kerja. Yo \& Surya (2015) dalam penelitiannya mendapatkan hasil bahwa beban kerja dan stres kerja memiliki hubungan positif dan signifikan. Penelitian oleh Lestari \& Utama (2017) menemukan hasil bahwa beban kerja berpengaruh positif dan signifikan terhadap stres kerja pada karyawan PT POS Indonesia (Persero) Pusat Denpasar di mana menunjukkan stres kerja akan meningkat saat beban kerja karyawan meningkat. Hasil penelitian ini juga didukung oleh penelitian yang dilakukan Kusuma \& Soesatyo (2014), Shabbir \& Naqvi (2017) serta Rizky dan Rizky \& Afrianty (2018),Wijaya (2018) dan Aujada, Saryadi, \& Nugraha (2015) juga menyatakan bahwa beban kerja berpengaruh positif signifikan terhadap stres kerja.

Berdasarkan hasil analisis pengaruh lingkungan kerja terhadap stres kerja diperoleh nilai signifikansi sebesar 0,011 dengan nilai koefisien beta 0,512 bernilai negatif. Nilai signifikansi $0,011<0,05$ mengindikasikan bahwa $\mathrm{H}_{0}$ ditolak dan $\mathrm{H}_{2}$ diterima. Hasil ini mempunyai arti bahwa lingkungan kerja berpengaruh negatif terhadap stres kerja pada karyawan Bharata Sport and Fashion. Kondisi lingkungan kerja yang kurang nyaman dapat menyebabkan stres kerja karyawan.

Jika merujuk pada jawaban responden terhadap pernyataan mengenai lingkungan kerja dalam kuisioner, didapatkan hasil bahwa karyawan tidak memiliki kepekaan yang tinggi terhadap suara, yang berarti bahwa lingkungan kerja mereka cukup bising sehingga sulit untuk mendengarkan bunyi tertentu. Lingkungan kerja yang bising, dapat memengaruhi stres kerja karyawan. Hasil jawaban kuisioner stres kerja memperlihatkan bahwa karyawan sering kali mengalami sakit kepala selama bekerja. Hal ini bisa disebabkan oleh kondisi lingkungan yang bising, yang membuat karyawan merasa pusing dan selanjutnya memengaruhi fokus dalam bekerja.

Hasil penelitian ini sesuai dengan penelitian sebelumnya Syaharudin, Utami, \& Andini (2017) mendapatkan hasil lingkungan kerja berpengaruh signifikan terhadap stres kerja. Penelitian tersebut menyatakan bahwa lingkungan kerja yang negatif dapat menyebabkan terjadinya peningkatan pada stres kerja dan menunjukkan terdapat pengaruh signifikan. Kristanti (2017) dalam penelitiannya mendapatkan hasil adanya pengaruh negatif dan signifikan lingkungan kerja baik secara fisik maupun non fisik terhadap stres kerja. Hal ini menunjukkan bahwa lingkungan kerja yang semakin kondusif akan mampu mengurangi stres kerja karyawan. Luma (2018) dalam penelitiannya menyatakan bahwa peningkatan lingkungan kerja guru dapat menurunkan stres kerja guru. Musyaddat \& Saufi 
(2017) menyatakan bahwa lingkungan kerja memiliki pengaruh negatif signifikan terhadap stres kerja. Penelitian oleh Rahajaan, Swasto, \& Rahardjo (2016) juga menyatakan lingkungan kerja berpengaruh negatif signifikan terhadap stres kerja.

Berdasarkan hasil analisis pengaruh beban kerja terhadap kinerja karyawan diperoleh nilai signifikansi sebesar 0,000 dengan nilai koefisien beta 0,384 bernilai negatif. Nilai signifikansi $0,000<0,05$ mengindikasikan bahwa $\mathrm{H}_{0}$ ditolak dan $\mathrm{H}_{3}$ diterima. Hasil ini mempunyai arti bahwa beban kerja berpengaruh negatif terhadap kinerja karyawan Bharata Sport and Fashion. Hasil penemuan ini mengindikasikan bahwa peningkatan beban kerja dapat menyebabkan penurunan pada kinerja karyawan Bharata Sport and Fashion.

Jika merujuk pada jawaban responden terhadap pernyataan mengenai beban kerja dalam kuisioner, didapatkan hasil bahwa karyawan merasa gelisah saat bekerja. Kegelisahan karyawan memengaruhi kinerja mereka, di mana karyawan tidak maksimal dalam melaksanakan tugas-tugas yang diberikan perusahaan. Tidak maksimalnya kinerja karyawan ditunjukkan oleh hasil jawaban kuisioner tentang kinerja karyawan di mana karyawan belum bisa memaksimalkan penggunaan sumber daya yang dibutuhkan dalam proses kerja.

Hasil penelitian ini sejalan dengan penelitian yang dilakukan Paramitadewi (2017). Paramitadewi (2017) menyatakan pengaruh negatif beban kerja pada kinerja karyawan berarti bahwa semakin rendah beban kerja pegawai, kinerja karyawan akan semakin tinggi. Penelitian Kusuma \& Soesatyo (2014) pada karyawan bagian produksi di PT Apie Indo Karunia mendapatkan hasil bahwa beban kerja berpengaruh negatif terhadap kinerja karyawan. Shabbir \& Naqvi (2017) menyatakan bahwa beban kerja berpengaruh negatif terhadap kinerja karyawan. Akob (2016) menyatakan bahwa beban kerja berpengaruh negatif signifikan terhadap kinerja karyawan. Hal yang sama juga dinyatakan oleh Wakoli (2016) dalam penelitiannya mengenai beban kerja terhadap kinerja guru di Bungoma, Kenya. Penelitian yang dilakukan oleh Chandra \& Adriansyah (2017) serta Iskandar \& Sembada (2012) menunjukkan bahwa adanya pengaruh negatif signifikan beban kerja terhadap kinerja karyawan. Gozali (2016) dalam penelitiannya juga menyatakan bahwa beban kerja berpengaruh negatif dan signifikan terhadap kinerja karyawan Badan Pusat Statistik di Kabupaten Deli Serdang dan Serdang Begawai.

Berdasarkan hasil analisis pengaruh lingkungan kerja terhadap kinerja karyawan diperoleh nilai signifikansi sebesar 0,000 dengan nilai koefisien beta 0,396 bernilai positif. Nilai signifikansi $0,000<0,05$ mengindikasikan bahwa $\mathrm{H}_{0}$ ditolak dan $\mathrm{H}_{4}$ diterima. Hasil ini mempunyai arti bahwa lingkungan kerja berpengaruh positif terhadap kinerja karyawan Bharata Sport and Fashion. Kondisi lingkungan kerja yang baik dan nyaman bagi karyawan akan meningkatkan kinerja karyawan di Bharata Sport and Fashion.

Jika merujuk pada jawaban responden terhadap pernyataan mengenai lingkungan kerja dalam kuisioner, didapatkan hasil bahwa karyawan tidak memiliki kepekaan yang tinggi terhadap suara, yang berarti bahwa lingkungan kerja mereka cukup bising sehingga sulit untuk mendengarkan bunyi tertentu. Lingkungan kerja yang bising dapat memengaruhi kinerja karena menganggu fokus karyawan. Pengaruh ini dapat dilihat dari hasil jawaban kuisioner kinerja 
karyawan yang memperlihatkan bahwa karyawan cenderung belum bisa menyelesaikan pekerjaan mereka tepat waktu.

Penelitian oleh Nguyen, Dang, \& Nguyen (2015) mendapatkan hasil serupa dan menyatakan bahwa lingkungan kerja berpengaruh positif dan signifikan terhadap kinerja karyawan. Jayaweera (2015) dalam penelitiannya mengenai lingkungan kerja dan kinerja karyawan mendapatkan hasil adanya pengaruh positif dan signifikan dari lingkungan kerja terhadap kinerja karyawan. Penelitian oleh Kristanti (2017) menunjukkan bahwa lingkungan kerja fisik dan lingkungan kerja non fisik berpengaruh positif dan signifikan terhadap kinerja karyawan. Hal ini menunjukkan bahwa semakin kondusif lingkungan kerja fisik dan lingkungan kerja non fisik yang ada maka kinerja karyawan akan meningkat. Penelitian terhadap karyawan universitas di Uganda oleh Wilson (2018) menunjukkan bahwa lingkungan kerja berpengaruh positif terhadap kinerja karyawan. Tulenan (2015) menyatakan bahwa lingkungan kerja berpengaruh positif signifikan terhadap kinerja karyawan. Harini \& Kartiwi (2018) menyatakan bahwa perbaikan pada lingkungan kerja dapat meningkatkan kinerja karyawan. Awaluddin (2016) dalam penelitiannya mengatakan lingkungan kerja berpengaruh positif terhadap kinerja karyawan. Penelitian oleh Dewi \& Frianto (2013) mendapatkan hasil yang serupa.

Berdasarkan hasil analisis pengaruh stres kerja terhadap kinerja karyawan diperoleh nilai signifikansi sebesar 0,001 dengan nilai koefisien beta 0,142 bernilai negatif. Nilai signifikansi $0,001<0,05$ mengindikasikan bahwa $\mathrm{H}_{0}$ ditolak dan $\mathrm{H}_{5}$ diterima. Hasil ini mempunyai arti bahwa stres kerja berpengaruh negatif terhadap kinerja karyawan Bharata Sport and Fashion.

Penelitian Ahmad et al. (2018) menunjukkan hasil serupa di mana terdapat pengaruh negatif dan signifikan dari stres kerja terhadap kinerja karyawan. Kotteeswari \& Sharief (2014) menyatakan bahwa stres kerja memengaruhi kinerja karyawan. Stres kerja membuat karyawan tidak mampu berkonsentrasi dengan baik pada pekerjaannya. Penelitian Vijayan (2018) mendapatkan hasil bahwa stres kerja berpengaruh negatif terhadap kinerja karyawan. Vijayan (2018) menyatakan bahwa manajemen bisa melakukan cara-cara yang diperlukan untuk bisa mengontrol tingkat stres kerja karyawan sehingga kinerja karyawan meningkat. Shahid (2012) menyatakan bahwa stres kerja berpengaruh negatif terhadap kinerja karyawan bank di Faisalabad, Pakistan. Ahmed \& Ramzan (2013) dalam penelitian pada sektor perbankan di Pakistan menyatakan bahwa stres kerja secara signifikan mengurangi kinerja karyawan. Saranani (2015) dan Kristanti (2017) menyatakan bahwa stres kerja berpengaruh negatif dan signifikan terhadap kinerja karyawan. Penelitian Kusuma \& Soesatyo (2014) juga menyatakan bahwa stres kerja berpengaruh negatif signifikan terhadap kinerja karyawan.

Hasil uji menunjukkan bahwa nilai $\mathrm{Z}$ sebesar 2,064 > 1,96, yang berartistres kerja merupakan variabel yang mampu memediasi pengaruh beban kerja terhadap kinerja karyawan pada Bharata Sport and Fashion. Hasil ini juga berarti bahwa beban kerja memiliki pengaruh tidak langsung terhadap kinerja karyawan melalui stres kerja. Pengujian sebelumnya menunjukkan bahwa beban kerja berpengaruh positif terhadap stres kerja dan berpengaruh negatif terhadap kinerja karyawan. Sementara stres kerja berpengaruh negatif terhadap kinerja karyawan. 
Berdasarkan hasil tersebut, dapat disimpulkan bahwa stres kerja memediasi pengaruh beban kerja terhadap kinerja karyawan.

Hasil ini didukung oleh penelitian yang dilakukan Shabbir \& Naqvi (2017) di mana beban kerja berpengaruh positif terhadap stres kerja dan berpengaruh negatif terhadap kinerja karyawan, serta pengaruh negatif stres kerja terhadap kinerja karyawan. Shabbir \& Naqvi (2017) juga mendapatkan hasil bahwa stres kerja mampu memediasi pengaruh beban kerja terhadap kinerja karyawan. Beban kerja memengaruhi karyawan sehingga menimbulkan stres kerja, yang kemudian menyebabkan penurunan kinerja karyawan.

Hasil uji menunjukkan bahwa nilai $Z$ hitung sebesar 3,333> 1,96,yang berartistres kerja mampu memediasi pengaruh lingkungan kerja terhadap kinerja karyawan pada Bharata Sport and Fashion. Hasil ini juga berarti bahwa lingkungan kerja berpengaruh secara tidak langsung terhadap kinerja karyawan melalui variabel stres kerja. Pengujian sebelumnya menunjukkan bahwa lingkungan berpengaruh positif terhadap stres kerja dan berpengaruh positif terhadap kinerja karyawan. Sementara stres kerja berpengaruh negatif terhadap kinerja karyawan. Berdasarkan hasil tersebut, dapat disimpulkan bahwa stres kerja memediasi pengaruh lingkungan kerja terhadap kinerja karyawan.Hasil ini mendukung penelitian yang dilakukan oleh Khuong \& Yen (2017).

Hasil penelitian ini mendukung teori yang digunakan sebagai dasar dalam pembuatan hipotesis bahwa beban kerja, lingkungan kerja, dan stres kerja dapat memengaruhi kinerja karyawan. Selain itu stres kerja juga mampu memediasi pengaruh beban kerja terhadap kinerja karyawan juga memediasi pengaruh lingkungan kerja terhadap kinerja karyawan. Ketika perusahaan mampu memberikan beban kerja yang sesuai dan membuat karyawan nyaman dengan lingkungan kerjanya, maka stres kerja akan berkurang yang kemudian berpengaruh kepada meningkatnya kinerja karyawan. Hal ini menunjukkan bahwa hasil memperkuat teori yang digunakan penelitian ini.

Penelitian ini menggunakan teori pertukaran sosial atau Social Exchange Theory sebagai acuan. Teori pertukaran sosial menyatakan bahwa karyawan akan menunjukkan perilaku yang positif berupa kinerja saat organisasi memberi mereka dukungan. Teori ini terdukung dalam penelitian ini karena semua hipotesis penelitian diterima. Karyawan akan memberikan timbal balik positif kepada perusahaan tempat mereka bekerja saat diperlakukan dengan baik.

Implikasi hasil penelitian ini memfokuskan pada kegunaan dan manfaat dari hasil penelitian untuk meningkatkan kinerja karyawan Bharata Sport and Fashion, dengan mempertimbangkan beban kerja, lingkungan kerja, dan stres kerja. Penelitian ini diharapkan mampu menjadi pertimbangan atau referensi dalam pengambilan keputusan di perusahaan atau organisasi sehingga mampu mengatasi serta mengurangi munculnya risiko permasalahan terkait dengan kinerja karyawan. Jika Bharata Sport and Fashion mampu memberikan beban kerja yang sesuai kepada karyawannya, dengan mempertimbangkan hal-hal seperti waktu istirahat maupun jumlah pekerjaan yang harus diselesaikan dalam waktu tertentu diharapkan karyawan akan lebih berkonsentrasi dan stres kerja bisa dihindari sehingga kinerja karyawan semakin baik. Lingkungan kerja yang baik dan aman 
juga perlu dipertimbangkan demi kenyamanan karyawan yang juga mampu meminimalisir timbulnya stres kerja dan meningkatkan kinerja karyawan.

Penelitian ini memiliki keterbatasan yang bisa dipertimbangkan untuk penelitian selanjutnya. Keterbatasan dalam penelitian ini yaitu subjek penelitian yang terbatas hanya pada karyawan di Bharata Sport and Fashion sehingga hasil penelitian yang didapat mungkin akan berbeda saat diterapkan pada karyawan di perusahaan lain dan kurangnya artikel pendukung hipotesis keenam dan ketujuh dalam penelitian ini mengenai peran stres kerja dalam memediasi pengaruh beban kerja terhadap kinerja karyawan dan peran stres kerja dalam memediasi pengaruh lingkungan kerja terhadap kinerja karyawan.

\section{SIMPULAN}

Berdasarkan hasil analisis penelitian dan hasil pembahasan pada bab sebelumnya maka simpulan dari penelitian ini adalah beban kerja berpengaruh positif terhadap stres kerja karyawan Bharata Sport and Fashion. Hal ini menunjukkan bahwa jika beban kerja semakin meningkat maka akan meningkatkan stres kerja karyawan Bharata Sport and Fashion. Lingkungan kerja berpengaruh negatif terhadap stres kerja karyawan Bharata Sport and Fashion. Hal ini menunjukkan bahwa jika lingkungan kerja semakin baikmaka stres kerja karyawan Bharata Sport and Fashion akan menurun. Beban kerja berpengaruh negatif terhadap kinerja karyawan Bharata Sport and Fashion. Hal ini menunjukkan bahwa jika beban kerja semakin meningkat maka kinerja karyawan Bharata Sport and Fashion akan menurun. Lingkungan kerja berpengaruh positif signifikan terhadap kinerja karyawan Bharata Sport and Fashion. Hal ini menunjukkan bahwa jika lingkungan kerja semakin baikmaka akan meningkatkan kinerja karyawan Bharata Sport and Fashion. Stres kerja berpengaruh negatif terhadap kinerja karyawan Bharata Sport and Fashion. Hal ini menunjukkan bahwa jika stres kerja semakin meningkat maka kinerja karyawan Bharata Sport and Fashion akan menurun. Stres kerja memediasi pengaruh beban kerja terhadap kinerja karyawan Bharata Sport and Fashion. Hal ini menunjukkan bahwa beban kerja memiliki pengaruh tidak langsung terhadap kinerja karyawan jika dimediasi oleh stres kerja. Stres kerja berperan sebagai pemediasi parsial.Stres kerja memediasi pengaruh lingkungan kerja terhadap kinerja karyawan Bharata Sport and Fashion. Hal ini menunjukkan bahwa lingkungan kerja memberikan pengaruh tidak langsung terhadap kinerja karyawan jika dimediasi oleh stres kerja. Stres kerja berperan sebagai pemediasi parsial.

Berdasarkan hasil penelitian ini, terdapat beberapa saran yang penulis berikan dengan harapan dapat digunakan sebagai bahan pertimbangan dalam menentukan kebijakan maupun pemecahan masalah yang terkait dengan kinerja karyawan, beban kerja, lingkungan kerja, dan stres kerja yaitu Bharata Sport and Fashion diharapkan memberi perhatian lebih kepada beban karyawan, agar karyawan tidak merasa tertekan ataupun stres dalam bekerja. Bharata Sport and Fashion diharapkan lebih memerhatikan keluhan karyawan terkait dengan lingkungan kerja terutama dari segi sumber suara sehingga karyawan merasa nyaman dan lebih fokus pada pekerjaannya. Bharata Sport and Fashion bisa 
mengadakan kegiatan di luar pekerjaan seperti outbond sehingga karyawan memiliki kesempatan untuk melepas penat dari pekerjaan mereka. Kegiatan ini diharapkan mampu mengurangi stres kerja karyawan di perusahaan. Bharata Sport and Fashion diharapkan bisa mengadakan pengawasan serta pelatihan terhadap karyawan di bidang produksi demi mengurangi kesalahan kerja dan meningkatkan kinerja karyawan. Peneliti selanjutnya bisa memperluas cakupan penelitian terkait kinerja karyawan ini, baik dengan menambahkan variabel bebas yang kemungkinan berpengaruh maupun dengan lokasi penelitian yang lebih kompleks.

\section{REFERENSI}

Ahmad, E. H., Maidin, A., Abdullah, T., Naiem, F., Buraerah, S., Handayanif, R., \& Prihantono, P. (2018). Relationship of Work Stress to the Performance of Intensive Care Unit Nurses in Makassar. American Journal of Public Health Research, 6(1), 18-20. https://doi.org/10.12691/ajphr-6-1-4

Ahmed, A., \& Ramzan, M. (2013). Effects of Job Stress on Employees Job Performance A Study on Banking Sector of Pakistan. IOSR Journal of Business and Management, 11(6), 61-68. https://doi.org/10.9790/487x1166168

Akob, M. (2016). Influence workload, work ethic and job satisfaction toward teacher's performance. Global Advanced Research Journals of Management and Business Studies, 5(7), 172-177.

Alkubaisi, M. M. (2015). How can Stress Affect Your Work Performance? Quantitative Field Study on Qatari Banking Sector. Business and Management Research, 4(1), 99-109. https://doi.org/10.5430/bmr.v4n1p99

Aujada, R., Saryadi, \& Nugraha, H. S. (2015). Pengaruh BebanKerja, Lingkungan Kerja Dan Pengawasan Terhadap Stres Kerja Karyawaan PT. Daya Manunggal Salatiga Departemen Weaving AJL II. DIPONEGORO JOURNAL OF SOCIAL AND POLITIC Tahun, 1(1), 1-10.

Awaluddin, M. (2016). Pengaruh Budaya Organisasi, Kepuasan, dan Lingkungan Kerja terhadap Kinerja Dosen UIN Alauddin Makassar. ASSETS, 6(1), 116125.

Chandra, R., \& Adriansyah, D. (2017). Pengaruh Beban Kerja dan Stres Kerja terhadap Kinerja Karyawan pada PT. Mega Auto Central Finance Cabang di Langsa. Jurnal Manajemen Dan Keuangan ISSN 2252-844X, 6(1), 670-678.

Darmawati, A. (2013). Pengaruh Kepuasan Kerja dan Komitmen Organisasi terhadap Organizational Citizenship Behavior (OCB). Jurnal Ekonomia, 9(1), 10-17. https://doi.org/https://doi.org/10.21831/economia.v9i1.1372 
Dewi, S. K., \& Frianto, A. (2013). Pengaruh Lingkungan Kerja Terhadap Kinerja Karyawan Melalui Motivasi. Jurnal Ilmiah Manajemen, 1(4), 1055-1065.

Dinas Perindustrian dan Perdagangan Provinsi Bali. (2016). Statistik Perindustrian dan Perdagangan Bali.

Gozali, N. (2016). The Influence of Workload and Individual Characteristic on Job Satisfaction and Its Impact on Employee Performance (A Case Study at Indonesian Regional Statistics Office (BPS) of Deli Serdang and Serdang Bedagai Regencies). Jurnal Bisnis Dan Manajemen Eksekutif, 1(1), 39-46.

Harini, S., \& Kartiwi, N. (2018). Workload, Work Environment and Employee Performance of Housekeeping. International Journal of Latest Engineering and Management Research (IJLEMR), 3(10), 15-22.

Iskandar, S., \& Sembada, G. G. (2012). Pengaruh Beban Kerja, Motivasi Dan Kepuasan Kerja Terhadap Kinerja Pegawai Bank BJB Cabang Padalarang. Jurnal Ekonomi, Bisnis \& Entrepreneurship, 6(1), 26-38. Retrieved from http://jurnal.stiepas.ac.id/index.php/jebe/article/view/16

Jayaweera, T. (2015). Impact of Work Environmental Factors on Job Performance, Mediating Role of Work Motivation: A Study of Hotel Sector in England. International Journal of Business and Management, 10(3), 271278. https://doi.org/10.5539/ijbm.v10n3p271

Khuong, M. N., \& Yen, V. H. (2017). Investigate the Effects of Job Stress on Employee Job Performance - A Case Study at Dong Xuyen Industrial Zone, Vietnam. International Journal of Trade, Economics and Finance, 7(2), 3137. https://doi.org/10.18178/ijtef.2016.7.2.495

Kotteeswari, M., \& Sharief, S. T. (2014). Job Stress and Its Impact on Employees' Performance a Study With Reference To Employees Working in Bpos. International Journal of Business and Administration Research Review, 2(4), $18-25$.

Kristanti, E. (2017). Pengaruh Lingkungan Kerja Fisik Dan Lingkungan Kerja Non Fisik Terhadap Stres Kerja Dan Dampaknya Terhadap Kinerja (Studi Pada Kantor Bersama Samsat Mojokerto Kota). Jurnal Ilmu Manajemen, 5(1), 1-10.

Kusuma, A. A., \& Soesatyo, Y. (2014). Pengaruh Beban Kerja terhadap Stres Kerja dan Dampaknya terhadap Kinerja Karyawan. Jurnal Ilmu Manajemen, 2(2), 375-386.

Lestari, N. K. A., \& Utama, I. W. M. (2017). Pengaruh Konflik Interpersonal Dan Beban Kerja Terdadap Stres Kerja Karyawan Pt Pos Indonesia (Persero) 
Pusat Denpasar. E-Jurnal Manajemen Unud, 6(12), 6357-6382.

Luma, M. (2018). Hubungan Lingkungan Kerja dengan Stres Kerja Guru di SDN Sekecamatan Batudaa Kabupaten Gorontalo. Jurnal Ilmiah Iqra', 10(1), 3946.

Musyaddat, L. E. S., \& Saufi, A. (2017). Pengaruh Dukungan Sosial, Beban Kerja dan Lingkungan Kerja terhadap Stres Kerja Perawat Rumah Sakit Jiwa Mutiara Sukma Provinsi Nusa Tenggara Barat. Jurnal Magister Manajemen, 6(4), 1-14.

Nguyen, P. D., Dang, C. X., \& Nguyen, L. D. (2015). Would Better Earning, Work Environment, and Promotion Opportunities Increase Employee Performance? An Investigation in State and Other Sectors in Vietnam. Public Organization Review, 15(4), 565-579. https://doi.org/10.1007/s11115-0140289-4

Paramitadewi, K. F. (2017). Pengaruh Beban Kerja Dan Kempetensi Terhadap Kinerja Pegawai Sekretariat Pemerintah Daerah Kabupaten Tabanan. EJournal Management Unud, 6(6), 3370-3397.

Pratama, P. Y. A., \& Satrya, I. H. (2018). Pengaruh Konflik Interpersonal Dan Beban Kerja Terhadap Stres Kerja Pada Pegawai Di Dinas Perhubungan Provinsi Bali. E-Jurnal Manajemen Universitas Udayana, 7(8), 4570. https://doi.org/10.24843/ejmunud.2018.v07.i08.p19

Rahajaan, T. E. V., Swasto, B., \& Rahardjo, K. (2016). Pengaruh Karakteristik Pekerjaan terhadap Lingkungan Kerja, Stres Kerja, Kepuasan Kerjadan Organizational Citizenship Behavior (Studi pada Pegawai Rumah Sakit Umum Daerah Karel Saidsuitubun Langgur). Jurnal Pengumpulan Data, 6(2), 104-116.

Rizky, D., \& Afrianty, T. W. (2018). Pengaruh Beban Kerja Terhadap Stres Kerja Dengan Work Life Balance Sebagai Variabel Intervening ( Studi Pada Dinas Sosial Provinsi Jawa Timur Surabaya ). Jurnal Administrasi Bisnis (JAB), 61(4), 47-53.

Robbins, S. P. (2006). Perilaku Organisasi (Edisi Lima). Jakarta: Erlangga.

Robbins, S. P., \& Judge, T. A. (2008). Organizational Behavior (12th ed.). Jakarta: Salemba Empat.

Saranani, F. (2015). Role conflict and stress effect on the performance of employees working in public works department. The International Journal Of Engineering And Science, 4(6), 1-10. 
Setyawan, A. (2018). Analisis Faktor-Faktor Yang Mempengaruhi Perusahaan Fabrikasi Lepas Pantai Di Batam Dan Karimun). Journal of Accounting \& Management Innovation, 2(1), 67-89.

Shabbir, B., \& Naqvi, R. (2017). Impact of Workload and Job Complexity on Employee Job Performance with the Moderating Role of Social Support and Mediating Role of Job Stress: A Study of Travel agencies in Rawalpindi, Islamabad and AJK. Journal of Accounting \& Marketing, 06(01), 1-7. https://doi.org/10.4172/2168-9601.1000214

Shahid, M. N. (2012). Work Stress and Employee Performance in Banking Sector Evidence From District Faisalabad, Pakistan. Asian Journal of Business and Management Sciences, 1(7), 38-47.

Syaharudin, M., Utami, W., \& Andini, A. P. (2017). Pengaruh Job Insecurity Dan Lingkungan Kerja Terhadap Turnover Intentions Melalui Stres Kerja Sebagai Variabel Intervening. Prosiding Seminar Nasional Dan Call For Paper Ekonomi Dan Bisnis, 312-325. Jember.

Tulenan, S. (2015). The Effect Of Work Environment And Compensation Toward Employee Performance At The Office Of State Assets And Auction Service Manado. Jurnal EMBA, 3(3), 672-682.

Vijayan, M. (2018). Impact of Job Stress on Employee'S Performance: an Empirical Study. I-Manager's Journal on Management, 11(1), 6. https://doi.org/10.26634/jmgt.11.1.8069

Wakoli, C. (2016). Effects of Workload on the Teachers Performance in Kanduyi Division, Bungoma District. International Journal of Science and Research, 5(10), 1215-1219. https://doi.org/10.21275/SUB154454

Wijaya, A. (2018). Pengaruh Beban Kerja terhadap Kepuasan Kerja dengan Stres Kerja sebagai Variabel Mediasi pada Pekerja di Hotel Maxone di Kota Malang. PARSIMONIA, 4(3), 278-288.

Wilson, K. G. (2018). Impact of Work Environment on Academic Staff Job Performance: Case of a Uganda University. Ijame, 4(4), 95-103. Retrieved from http://www.managementjournal.info/index.php/IJAME/article/view/395

Yo, P. M. P., \& Surya, I. B. K. (2015). Pengaruh Beban Kerja terhadap Kepuasan Kerja dengan Stres Kerja sebagai Variabel Mediasi. E-Journal Management Unud, 4(5), 1149-1165. 